\title{
Public spheres, counter public spheres ... and proletarian public spheres: the case of Facebook group of the Hellenic Halyvourgia S.A. strikers in Greece 2011-2012
}

\author{
Regina Zervou \\ Institute for Education Policy, Greece \\ E-mail: rzervou@gmail.com
}

\begin{abstract}
The 9-month strike in Hellenic Halyvourgia S.A. marked the first period of social struggles against austerity policies in Greece and was embraced by a huge solidarity movement both at national and international level. During that time the only digital voice of the strikers was a Facebook group that, even created more than a year before, became a vivid gathering of the strikers, their relatives and people in solidarity, even some counter strikers. The paper exa-

mines the visual and text data of the Facebook group during the nine months of the strike and focuses both to the subjects, the members of the group and to the discourse pronounced by them. The question that rises from that and similar researches is whether cyberspace, and SNS in particular, could serve for the formation of a community of struggle and, furthermore, to what German scholars Negt and Kluge once called a 'proletarian public sphere'.
\end{abstract}

\section{INTRODUCTION}

7 HE overwhelming predominance of internet, with its facets of interactivity called "social me-

1 dia", has created a new virtual public realm unknown up to three decades ago. This realm has been called 'digital public sphere', following the denomination given by the German philosopher Junger Habermas to define the sphere of private people come together as a public. It was specifically a part of 'civil society' which at the same time established itself as the realm of commodity exchange and social labor governed by its own laws.'(Habermas, 1991)

What where the differences and the likes of a bourgeois public sphere at the end of the $19^{\text {th }}$ century and the one created by the evolution of telematics in the aura of the $20^{\text {th }}$ century? Given that the development of the media is accompanied by far - reaching changes in the structure of human perception, ( Kodler - Bunte, Lennox and Lennox, 1975) the use of internet by the $42,3 \%$ of the world population (87,7 and 70,5 in North America and Europe respectively) ${ }^{1}$ marks a new

Data de submissão: 2016-10-18. Data de aprovação: 2017-05-04.

A Revista Estudos em Comunicação é financiada por Fundos FEDER através do Programa Operacional Factores de Competitividade - COMPETE e por Fundos Nacionais através da FCT - Fundação para a Ciência e a Tecnologia no âmbito do projeto Comunicação, Filosofia e Humanidades (LabCom.IFP) UID/CCI/00661/2013.

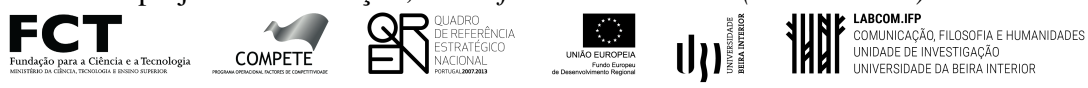

1. Information found in www.internetworldstats.com/stats.htm 
era in the way people conceive their role in the public sphere. Characterized by multiplicity and diversity of publics (Dahlgren, 1995: 11-23, 2005: 148), this new public spheres extend the role of the public in the social and political arena. (Papacharissi, 2002)

Though internet is a medium constructed in the capitalist era, part and parcel of a social and political world (Jones, 1997), the impact social media have upon the organization and propagation of social struggles in the last two decades, the case of the Zapatistas site being one of the first and most famous among them (Downing, 2001), is largely acknowledged. Since then, new media played an increasingly important role in the way social activism is perceived and performed, up to the point to be called a 'Fifth International'. According to Waterman 'the worldwide spread, social depth, technical complexity and infinite variety of computer application have finally brought a significant number of emancipatory thinkers and movements to confront communication as central to social process.' (Waterman 1992:14) Even though criticism has been exerted to the supporters of the virtual public sphere (Habermas, 2006; see also Downey and Fenton, 2003: 189), no one can deny that the so - called social media, especially the Social Networking Sites (SNS) with their dynamic interactivity, played a crucial role in many major social movements of the last decades. 'Recognizing the dynamics of networking and collaborative action among actors in the civil society is a crucial element for any conceptualization of the modern public sphere."'(Milioni, 2009: 412). The increasingly important role played by the digital social fora and SNS in organizing major protests and spreading the word of disobedience and insurrection has diluted previous doubts about whether cyberspace creates a public space which enhances dialogue or a public sphere, which enhances democracy (Jones 1997, Papacharissi, 2002) and allowed social scientists to refer to it as a counter- public sphere opposed to the dominant - bourgeois public sphere which is mostly represented by the institutional mass media. As counter publics 'function as bases and training rounds for agitational activities directed toward wider publics' (Frazer, $1990: 68$ ), the counter public spheres created by various types of social media have the possibility of intervening, directing and/or even transforming social mobilizations.” (Warner, 2002: 88)

\section{Digital COUNTER PUblic SPHERES: INDYMEDiA ATHENS AND THE GREEK PROTESTS IN DECEMBER 2008, FACEBOOK AND THE RESISTANCE IN EGYPT}

Before advancing to the core of this study, that is the use of Facebook during the nine month strike in the steel factory Hellenic Halyvourgia (HH) of Aspropyrgos, Attica, let us first take a comparative look in two major cases of social uprisings, the so called 'Greek protests' or 'Greek riots' in December 2008 and the Arab Spring revolt in Egypt in January 2010, both situated in the socio - geographical space of Eastern Mediterranean and known for the decisive role played by the cyberspace activity.

The outburst of the youth unrest, caused by the assassination of an adolescent in the centre of Athens on the $6^{\text {th }}$ of Decenber of 2008, was first announced in the website Indymedia Athens by a post uploaded less than one hour after the incident (following an urban myth, the post was uploaded by the resident of a provincial town after a phone call from Athens). Indymedia Athens is the local chapter of Network of Independent Media Centers (NIMC), an international network which emerged around the protests against the World Trade Organization in Seattle in 1999, defi- 
Public spheres, counter public spheres ... and proletarian public spheres: the case of Facebook group of the Hellenic Halyvourgia S.A. strikers in Greece 2011-2012

ned as an attempt by media activists to offer new forms of alternative media use of the Internet and to widen the possibilities for those online to participate openly in its construction (Smith, 2001). Indymedia is structured around the premise that media production and consumption should be a many-to-many process, in contrast to the traditional 'representative' one-to-many media approach. Thus, at the same time as globally publicizing 'local' grassroots events, Indymedia offers a far broader challenge (Pickerill, 2007). Its inherent democratic, chaotic, decentralized nature and freedom from official control has made internet a strong medium for civil society (Platon and Deuze, 2003 : 337). It's chaotic and decentralized nature is mostly evident in Indymedia Athens. The detailed research of Dimitra Milioni (Milioni, 2009), which focuses on postings published in a 10days period in 2002, enlightens what is highly known to the Greek activists engaged in the use of Indymedia Athens: information and analysis very often give place to passionate comments and scorning remarks, while the accuracy of data could not always be proven. These features, though sometimes bothersome during linear daily routine, were proven to be a gift in the December 2008 unrest, when Indymedia functioned predominantly as an in- group communication network, oriented primarily to serve the needs of activists for information. This is why 'the editorial team was discouraging users to post comments and opinions due to the urgency of the circumstances and the huge traffic on the website' and 'also underscored the need for accuracy, advising users to post only verified information.' (Milioni, 2012: 14-15). After the first days of clashes, even though less posts were published, there was given place to more discussion and analysis texts. The in-group communication of activists referred above literary transformed Indymedia Athens, for a period of about one and a half month - while multiplied actions around Athens and other places in Greece echoed the reminiscences of the first days of totally challenging the society - into a flourishing communitas $^{2}$ of people who shared information, opinions, thoughts, analysis but also feelings about a major social event they had just experienced.

Internet was of major importance for the Egyptian activists during the 25 January 2011 revolt against the Mubarak authoritarian regime, though the digital means used by the activists were different. Here we notice the predominance of SNS, notably Facebook. Egypt counts for about 5 million users of Facebook, which is the second most accessed site after Google (Spot On, 2010), while its penetration in Northern Africa is second next only to North America. (Mc Carthy, 2010). For societies eager to communicate ideas, such as Egypt under Mubarak's rule, SNS are a more manageable way to enter into the digital reality than structured sites with clear political command, such as IMC, fruit of the over two centuries social, unionist and political culture not familiar to a society living under almost colonial rule. Even compared to the Zapatistas indigenous movement that modeled a site to propagate their aims and goals, the eruptive society of Egypt found its path to express rage and organize resistance through a medium created for the communicational needs of the university and college students in the USA just a few years ago.

Facebook is an internet tool accessible to many, as it is considered to be 'very easy' or 'easy'.(Hart, Ridley, Taher, Sas, Dix, 2008). One can easily create an account, upload archives, express opinion and, much more, create groups in which he/she has the right to accept or

2. About the notion of communitas as the structure of a spontaneous community which shares feelings and purposes see V. Turner, Dramas, fields and metaphors -symbolic action in human society, Ithaca and London 1974, Cornell University Press, pp. 127-132. 
deny membership. Some of these groups are considered of crucial importance for the evolution of the Egyptian social movement towards the eruption of the $25^{\text {th }}$ January, like 'We are all Khalid Said', ' 6 th of April Youth Movement' (Kickpatrick and Sanger, 2011), the 'Facebook girl'. As Albrecht Hofheinz notes: 'Where traditional political parties had failed, where blogging fatigue had set in, Facebook groups were going to succeed, even if the people behind them were unaware of the momentous change the researcher was uncovering: 'revolutions without revolutionairies'. (Hofheinz, 2011).

But revolutionaries did exist in Egypt in the wake of the 21th century. Egypt has experienced a wave of unprecedented labour protests since December 2006 (El Mahdi, 2011). The ' 6 "th of April Youth Movement' supported, not created the $6^{\text {th }}$ April 2008 general strike, As Husam al-Hamalawi pointed out, grassroot movement on the ground (the unionists in Mahalla textile industry and in other working places along the country) accounted more for the making or breaking of a successful strike than a mouse click on Facebook (al-Hamalawi, 2008c), proven to be right by the unsuccessful attempt made by Facebook activists to provoke a strike just one month after, the $4^{\text {th }}$ of May.

In the $25^{\text {th }}$ of January revolt, that ended the Mubarak regime, the role of Facebook was highly praised by many, while the one of the continuing labor struggles was not so much studied, though strikes, together with demonstrations, were banned in the aftermath of Mubarak's resignation under the pretext that they challenged Egypt's future security. (Sallam, 2011) ${ }^{3}$. Maybe this happens because the social media are a phenomenon so blatantly new and rapidly globalized that social researchers direct their attention to it, overlooking class struggles as something known, of the past. The question of whether the new media are a mere tool or can bring major social events such as general strikes or revolts, and, in case they are a tool, how powerful this tool can be in order to change dynamics on the ground, is not, and maybe cannot, be answered by the academic community in an absolute way since 'we haven't come past the stage of hypothesis building.' (Hofheinz, ibid.) In this paper we will give a close look in an example where the social event (a strike) and the internet tool (a Facebook group) went 'hand in hand' from the beginning to the end, referring constantly one to the other: the case of the 9 month strike in Greek Steel Industry and the Facebook group 'Come one steel worker, come all'.

\section{ON Negt AND KLUGe}

In 1972, ten years after the publication of Habermas' book on the public sphere, Negt and Kluge published their own attempt to analyze the form public sphere has taken in the end of the $20^{\text {th }}$ century. They called it the industrialized public sphere of production, that is the public sphere created by computers, the mass media, the media cartel, the combined public relations and legal departments of conglomerates and interest groups, and, finally, reality itself as a public sphere transformed by production.

3. Only three days after Mubarak's resignation, the Supreme Council released Communiqué 5, which outlines the negative impact of continuing protests on the economy and calls on labor and professional syndicates to help bring about a return to normalcy in everyday life. www.sis.gov.eg/Ar/Story.aspx?sid=44125 
Public spheres, counter public spheres ... and proletarian public spheres: the case of Facebook group of the Hellenic Halyvourgia S.A. strikers in Greece 2011-2012

On the other hand there is what Habermas had called 'a variant of a plebian public sphere that has, as it were, been suppressed within the historical process'."(Habermas, 1989:8). According to Negt and Kluge, this is the 'proletarian public sphere', which will be the one to express and organize the experience and interests of the subordinate classes in their way to emancipation, the working-class's defense organization. ${ }^{4}$ The proletarian forms of experience are not based upon control over products but upon the experience of production itself. 'The use-value characteristics of the proletarian public sphere are fundamentally dependent on class interests, on the specific relationship between a particular interest that is linked to a specific public sphere and the whole of society.' (Negt and Kluge 1993: $3^{5}$ ).

The working people, though having their own experiences, aren't able to organize and analyze them because the media whereby experience is constituted all participate in the mystificatory context of commodity fetishism. All the experience they gain in this industrialized public sphere of production, distanced as they are from the production process, appears as nothing more than a gigantic, cumulative 'private interest', not as a collective mode of production for qualitatively new forms of public sphere and public consciousness.

"The proletarian context of living is thus split into two halves. One is reabsorbed into the new public spheres of production and participates in the process of industrialization; the other is disqualified in relation to the framework established by systems of production and the public sphere of production that determine society. The proletarian context of living does not as such lose its experiential value; however, the experience bound up in it is rendered "incomprehensible"in terms of social communication: ultimately, it becomes a private experience." (ibid, 18)

In the factory exists no public sphere. The bourgeois society that created the public sphere as a place to enhance dialogue, transparency and democracy, doesn't let any light enter in the places where the process of production is held. The authors, with references to contemporary to them labor legislation (Arthur Nikisch, Arbeitsrecht, vol. 3: Betriebsverfassungsrecht, 2d edition), note: the so-called public sphere of the factory can no longer be portrayed as "public."It constitutes an arcane realm, which is protected by factory security, law-enforcement measures, and

4. They use the term 'proletarian' acknowledging that they are using a word that in their times had 'taken on an attenuated, indeed an anachronistic, sense. Yet the real conditions it denotes belong to the present, and there is no other word for them. We believe it is wrong to allow words to become obsolete before there is a change in the objects they denote.' (Negt and Kluge, 1993: xlv). Proletarian Public sphere is not a term firstly used by Negt and Kluge, as they note in their book. It has been used during the inter-war in Germany to denote mostly the public sphere of the Communist Party, even though the authors declare that 'The proletarian public sphere is not exactly that which could be characterized as the public sphere of the party... Here the concept has an almost spontaneous, ad hoc quality, which is attributed to the masses from without. The situation is characterized by a state of affairs in which party organization and the masses are no longer united by a common experiential context', (Negt and Kluge, 1993: xlv, fn. 2)

5. Here there is a small collection of articles published in the web by various organizations, newspapers or sites during the nine months of the strike, showing the international interest this strike had raised. https://geomylo.wordpres ss.com/2011/12/10/one-month-strike-at-halyvourgia-a-e-steel-industry-in-thriasio-elefsina/, www.grreporter.info/en/st rike_workers_hellenic_steel_company_has_been_going_65_days_already/5670, wwwpetepoetry-bullybuster.blogspot .gr/2012/03/steel-workers-strike-in-greece-made-in.html, http://blog.occupiedlondon.org/tag/steelworkers-indefinite-w ildcat-strike/, http://roarmag.org/2012/07/greek-steel-workers-strike-police/, www.theguardian.com/world/greek-elect ion-blog-2012/2012/jun/14/greece-steelworks-strike\#start-of-comments, www.workersliberty.org/story/2012/07/11/ste el-and-call-centre-workers-fight-back-greece, www.wageindicator.org/main/labour-laws/collective-bargaining/2012/ne ws-items-2012/greece-steel-workers-strike-ends-in-tear-gas-august-1-2012 
alleged legal institutions. This lies in sharp contrast to the fact that the labor taking place in factories rests on cooperation and social interrelations and spans the greater part of the lifetime of employees and the organized labor force; it also lies in contrast to the overwhelming influence that the domain of production exerts on the public sphere. These circumstances are recognized only in the shape of the public sphere labor of the factory, which is itself manufactured on a nonpublic basis. (ibid, 50)

The interests of workers can be organized only if they enter into a context of living, in other words into a proletarian public sphere. Only then they have the chance to develop as interests, instead of remaining mere possibilities. The proletarian public sphere assumes the active function of mediating between social being and conscience, it provides the foundations for the potential formation of class consciousness. (Knodler - Bunte, 1975).

\section{RESEARCH QUESTIONS}

According to Negt and Kluge, the proletarian public sphere is a matter of the future, to be created with the convergence of three very different factors, that is the interest of the producing class, an interaction which can relate specific interests in the realm of production to the entire society and the predominance of the proletarian public sphere over the inhibiting and destructive influences emanating from the declining bourgeois public sphere. (ibid, 56) Nevertheless, in periods of historical transition, such as the austerity stricken Greek everyday life in the last five years, when 'the illusory public sphere becomes decisive for the actions of individuals' (Negt and Kluge, 1993: 77), proletarian public spheres, small and dispersed maybe, utilizing the framework given to them by the organizational form of the 'dictatorship of the bourgeoisie', that is the Habermas' public sphere, may be created.

When the term 'proletarian' instead of ' counter' public sphere is used (as it was the case with the of Greek riots and the Egyptian revolt, referred above) the reason is to denote that, while the counter - public spheres enhance dialogue and democracy, help in exchanging views, form collectivities and organize struggle, a proletarian public sphere expresses the experience and interests of the workers based on the experience of production itself.

The main research question is whether, and it what terms, the Facebook group 'Come one steel worker, come all' that gathered strikers, people in solidarity, even counter - strikers, for the crucial period of the nine months strike in the steel factory of the 'Hellenic Halyvourgia S.A.' consists an example of proletarian public sphere. Is the mere fact that most of the members were working in the same plant, and by that fact they constituted a physical, not only digital, communitas enough to segregate this Facebook group from other digital entities that create counter public spheres and attribute to it the category of proletarian public sphere? What was the function of the group during these months, did it play a decisive role to the progress of the strike? Did it finally managed, via a medium created in the commodity market, to express and organize the experience and interests of the workers, to become their defense organization? 
Public spheres, counter public spheres ... and proletarian public spheres: the case of Facebook group of the Hellenic Halyvourgia S.A. strikers in Greece 2011-2012

\section{The STRike in Hellenic HALYvourgia S.A. IN SHORT}

The strike in the factory of 'Hellenic Halyvourgia S.A.' in Aspropirgos, Attica, started on October $31^{\text {st }} 2011$ after the 400 workers' denial to answer to the entrepreneur's blackmail to choose between five-hour work and up to $40 \%$ cut off of their wages or 180 dismissals. It lasted 9 months and was marked by an unprecedented wave of solidarity (Gialis and Herod 2014, Bithymitris, 2016). All kind of labour, social and political collectivities saw in the strikers' struggle the fight they wanted to launch against neoliberal austerity and urged to help them, providing them with money and food. ${ }^{6}$ Behind them a miraculous world of dozens of strikes, forgotten by the regime's media, was revealed. Strikes in the food industry, telecommunications and unpaid journalists put themselves on the side of the steel factory strikers, forming a front against the attack to labour rights.

It challenged the ruling's elite narrative that the Greeks lived in a totally deindustrialized country that produced nothing and was plunged in consumption. hence the austerity policies. The austerity stricken working force of the country was identified with the 400 workers of HH that illustrated an example of resistance. (Henley, The Guardian, (14/6/2012)

On February 2012 a counter-strike mechanism was organized by some ten of workers who, together with clerks of the factory, began to take action against the strikers. At the end of May, the group of counter-strikers counted with about 30 members. The $17^{\text {th }}$ June elections in Greece gave a three - party government engaged to go on with the demands of IMF and the E.U. A.Samaras, the prime - minister, had declared some days before the elections that he won't let a bunch of communist - driven strikers to close down factories, as in the case of HH S.A. A.Georgiadis, ultra right wing parliamentarian, declared that the government should start its job by proving it has the will to stop an illegal strike. (Mottas, OpEdNews, 20/7/2012).6 At 3 o'clock in the morning, $20^{\text {th }}$ of July, riot police occupied the gate of the factory, in order to let the counter-strikers enter. Strike lasted one more week, with fierce battles among the workers and people in solidarity with the riot police, until, on $28^{\text {th }}$ July, it was suspended as the assembly of strikers decided. On July $30^{\text {th }}$ the strikers went back to work, though the plant has not fully functioned again. Most of the workers were fired with the newly implied measure on collective dismissals on June 2014. 25 among them had been sentenced on April 2014 with sentences of 23 months based on accusations by the counter-strikers.

\section{'COME ONE STEELWORKER, COME ALL': THE DIGITAL VOICE OF THE STRIKERS}

The Facebook group 'come one steelworker, come all', paraphrasing a part of the Christian Liturgy of the Faithfull, was created on October 2010 as 'a group some 13 people who were working together for chatting and talking trivialities.' It was the first media to announce the beginning of the strike the very hour it happened: at afternoon., October $31^{\text {st }}, 2011$. The posting was entitled 'The struggle in steelworks starts now', and was commented as follows:

6. Translated in the following link: http://leninreloaded.blogspot.gr/2012/07/steelworkers-strike-lies-upon-lies.ht $\mathrm{ml}$ 
S.B. fellows, everybody out for the 18 colleagues because tomorrow there would be another 18

S.G. What happened, when did they get fired?

S.B: Today at noon

S.G.: What happened, did you get out?

P.K.: Get shocked, everybody in the gate

News were spread that there was a Facebook group that gathered strikers and there they could exchange information, so many colleagues rushed to become its members. According to S. I was the administrator responsible to select the ones to enter. In the beginning we even let counterstrikers enter.' By the end of February the group counted more than 100 members. Their number increased rapidly and reached, by the end of the strike, 300. One administrator narrates: I accepted membership of people I knew or others that were recommended to me. If a colleague told me' I know him, he comes to the gate, he is supporting our struggle, I would accept him as a member.

This group remained the main digital expression of the nine months' strike, and even after. It may seem strange that a social event of such importance would not have created a site or a blog, in a time when every small neighborhood gathering had one. Taking into consideration that the strike, since its early days, was politically uttered by the media of the Communist Party and its union, PAME, it followed their norms of propagating struggle. The Communist Party was late in opting for digital media and never enhanced the interactivity arising from them. Nevertheless, some leftist activists created two blogs, We are steelworkers in struggle and Website for the Solidarity to the steelworkers on strike. Although the second website managed to gather a considerable amount of acts or votes of solidarity (235 in number), the first one that intended to give voice to the strikers had very poor performance, with only 10 postings, and practically served only to crossrefer to their Facebook group. The strikers opted for the digital means that was closer to their perception and stances, needed not enhanced skills, didn't obey to strict norms and regulations and was characterized by increased interactivity: that was Facebook, the digital expression of the technologically illiterate. The group provided direct information about events, announcements, pictures of people that were standing by us, eminent people who visited the chairman of the union. It was a good thing to know what was going on.

According to Facebook's visibility rule. (Zhao, Grasmuck and Martin 2008: 1823), 'Come one steelworker, come all' was an open group and all postings were public. When the conflict among strikers and counter strikers was transferred in the digital public sphere, some of the counter strikers blocked the function of the group, as Facebook legislation allows. During the blockage time the strikers created a closed group called ' The steelworkers' struggle', in which counterstrikers were excluded, as it explicitly declared in the 'group information' tag.: I'm sorry, I won't take any counter strikers. This group still serves as a means of communication among the people who once belonged to the strike's community.

\section{Methodology}

The research focuses both on the subjects, the members of the group, and the discourse pronounced by them. Therefore, quantitative and, basically, qualitative methods have been implied. 
Public spheres, counter public spheres ... and proletarian public spheres: the case of Facebook group of the Hellenic Halyvourgia S.A. strikers in Greece 2011-2012

The author, being a member of the Facebook group since January 2012, has conducted semiguided interviews with members of the group. The sample used for content analysis was the photo archives of both groups 'Come one steelworker, come all' and 'The steelworkers' struggle' during the period of the strike, chosen because it is a better way the whole process of the nine months' strike may be depicted. Moreover, the period between 20-30 July 2012 (the week after the riot police's invasion and the end of the strike) is also studied.

As for the users, Facebook is a digital social media that enables 'nonymity' (Zhao S. Grasmuck S. and Martin J. 2008), that is the opposite of the Greek word anonymity for some English speaking users. As Facebook accounts are linked with e-mail addresses and people in general, and the users of the group in particular, used their real names in their accounts, the online relations were based on offline - ones, thus called "anchored relationships" (Zhao, 2006). Moreover, the members of the group formed and offline turnerian communitas, as they shared a reality conceived as a breach in their everyday life - that was the period of the strike. The study of the group's members is pursued on the variables of gender, ethnicity and role. As for the last one, there are three values: steelworker (striker or counter-striker), relative and supporter.

Content analysis is carried through the number of postings gathered in the photo archive of both Facebook groups. The postings are evaluated according to their content as the political activity of the strikers, acts of solidarity and scenes of the everyday life formed by the strike's reality. The postings are also evaluated according to number of comments accompanying each posting (values given were titled, reactive and interactive) and the type of posting (photo, video, uploaded material). A discourse analysis on the key-words used by the strikers to define their struggle is carried out.

The semi-guided interviews conducted with strikers, relatives and supporters, helped treating with issues difficult to handle through the written digital discourse, such as the relation between the mediated communication in the group and the FtF one in the factory, the way workers and supporters got members of the group and its function and efficacy during the strike. Finally, the researcher, through data analysis and experience gained in the field, tries to estimate whether the digital space created during those months of the strike would consist a proletarian public sphere, the way Negt and Klude introduced the term.

\section{THE MEMBERS OF THE STRIKE COMMUNITY}

The members of the group were tracked down through the photo archive. Since all members were deleted when the group was reported, only the ones that uploaded or commented could be registered. This is far below the total number of actual members, since many of them followed the flux of information but didn't intervene, since fear, as always, prevailed. Many of the strikers entered and read but they didn't write because they were afraid. All of them were worried. Many were with one foot on each side, yes but... That's why they didn't write. They didn't want to open up, for fear of losing their jobs, the ones fired for if there was a chance to get back to work.

Out of 106 members registered we can identify three different roles : we surveyed 41 steelworkers, 18 relatives and 47 supporters. 
The absence of the union's board members, the ones who expressed the political demands of the strike, must be noticed. This is due to the reluctance of the traditional unionists to understand and accept this totally new kind of communication and the incapability to use this new media. The steelworkers who did participate in the Facebook group shared various political beliefs, ranging from anarchism to far right, even though left political views prevailed. .Mostly the strikers knew their rights and they tried to defend them. It was of a wide political range, even members of the Golden Dawn. The group served as a means of keeping the striker's morale high. Some of us had our moral raised, so it wasn't necessary, but others didn't and they needed some invigoration, by seeing that people were in our side or even with some songs.

As the long - lasting strike became a major event not only for the strikers themselves but also for their families, who played a crucial role in the strikers' stance encouraging or accusing them, some of them joined the group in order to express their opinion. They even learned how to use computers for joining the group. As S., a steelworker's wife, notes: I didn't know anything about computers, not even how to put it on, but thanks to my daughter I learned how to upload, write some comments and all these things that seem simple for many people but for me it was all new. The ones participating in the group strongly advocated their husband's or father's stance as a striker and propagated the rights of the strike.

The comparatively high number of supporters helps in estimating the importance solidarity movement played in that particular strike. The group helped the contact between strikers and those who took sides with us. It gave a push to the solidarity movement. We wrote. 'Everybody at the gate' and next morning very many people were gathered. A grandpa told me once: My son told me that he read on the computer that people pass by and leave things for you.' He went then to the kiosk and bought us cigarettes and chocolates. In a time when mainstream media ostentatiously ignored strikes, Facebook managed to create a community of strikers and supporters who were eager to learn more and come in direct contact with one another. The solidarity expressed in the Facebook group was not one-sided. All the groups that came in support could expose their action. Supporters were active members of the group. They uploaded news or photos, conversed with the strikers, got involved in heated dialogues with the counter strikers, commented and were far more critical.

37 women, either relatives or supporters, participated in the Facebook group. Though a committee of the strikers' wives has been set up, aiming to involve women into the struggle, their participation in the Facebook group was not analogous, since many of them, due to their age, were not familiar with new media technologies. (Royal 2008) Thus, the first postings come from supporters and only on January $8^{\text {th }}$ a wife uploaded some photos.

Though some researches stress on the difference of male and female cyber discourse, characterizing male speech as 'more coarse and abusive' and female discourse 'more supportive and attenuated' (Savicki, Lingenfelter and Kelley 1996), there is a 'generalization problem' as often we draw conclusions without making distinctions between different groups of men and women. (Helsper, 2010) As for this particular Facebook group members, we may discern two distinctive female groups: the strikers' relatives - mostly wives or other women of their close environment, and the activists. Originating from a totally different social and cultural milieu, their discourse was blatantly different as well. After decades of living behind closed doors, very few of the strikers' 
wives uploaded, or even posted comments, and their discourse was emotional, elliptic and supportive, expressing personal opinions and self - disclosure. (Herring, 1994) Most of them were housewives, not used to participate in public dialogue. The supporters - activists had a totally different approach. Their postings and uploads were strongly political, they provoked and participated in heated conversations. Their discourse was much closer to a supposed male one, with frequent and lengthy postings, both emotional and structured, for most of them they were educated and unionists.

At the outburst of the strike, 8 immigrant workers were employed by the Hellenic Steelworks S.A. Most of them got involved with the strike, to the point that one of them was arrested by the riot police. Three of the immigrants became members of the Facebook group and uploaded photos and comments. The discourse was limited, however there was an active interaction among them and the other members of the group. Though in the workers' milieu conservative and racist ideas are quite popular, studying the postings one can find nationalist propaganda but no word against migrant workers.

However, the most intriguing group among the users was that of the counter-strikers. They got members of the group in the start as nobody would expect it to take those dimensions. To get to the court. As the months passed by some took parts with the owner and served as its mechanism. Others wandered about the use of a long - lasting strike. As the rest of their colleagues, most of the counter strikers just received information, while few of them were engaged in conversations. These conversations were heated end of February, when a group of counter strikers appeared backed by riot police protesting against the strike. Part of the comments:

- Most of us have talked to each other and had a cup of coffee and now we turn into cannibals. I'm still a man, not an animal, and respect all my colleagues.

- I also have worked several years in the plant and I respect every colleague, but... against us? After 122 days together, no matter what the dissents are. Whatever you believe, there are LIMITS, everywhere.

As weeks passed and no solution seemed possible, nonymous and anonymous attacks against the strikers multiplied:

6 May ( the day of the first national elections):

- We were waiting something out of the elections but nothing. The Communist Party achieved that because we believed that we could eat for free. Manessis gave us a chance we didn't take.

- Big of a chance... You would work five hours a day and we would get hungry five months earlier, without even resisting

- We won't get to work after 110 people having been fired.

- Nice words, told without thinking. OK, let's go eat from the rubbish so we won't do the boss's favor. I think your brains stopped functioning

- No brain is left, just the sun and the plastic chair

- The head of the union will make us a swimming pool. Oh God, I'm so sorry for all of us.

- So you want us to go back to work with so many people fired? 
- I want a solution, I want our lives back

- Nothing's going to be like it was before. NEVER.

- It's on our hand. At least we tried. Others didn't have the courage to carry on a struggle like that. I'm proud I did it but I cannot go on anymore.

On June 6, after one of the numerous incidents among strikers and counter - strikers in front of the plant's gate, that marked the last month of the strike:

- The police force was very discrete.

- They were discrete because they didn't want to hurt the feelings of those who had nothing to do there (referring to the supporters)

- Those were there to protect our struggle, whether you like it or not.

- The strike was our job. Since the very beginning many got there out of the blue and now it's too late.

- When you take food and money from the solidarity fund do you think about that? Everyone who supports us all this time has the right to be there and fight. That's the way all of us will win. OK?

- I don't blame them, I say it's too late, they applause and then make fun of us.

- If you go outside of a super market and see the way everyday people support us, you will feel proud of being a steelworker.

- Take me with you because I haven't been to a supermarket since Christmas

The paper insists on presenting material particularly from the discourse pronounced among strikers and challengers or counter-strikers because it is a way of demonstrating how working class gives form to class conscience. Taking a closer look to the postings above, one may depict a blatant distance in the opinions expressed on the two emblematic notions that epitomized the struggle against austerity and impoverishment in Greece: dignity and solidarity (Dimitriou, 2011). Dignity towards all the colleagues, no matter what they stand for. But are there any limits? Is it dignity to turn against your class? Are the supporters intruders who came uninvited to change the way of things or are they class allies who will help leading a difficult struggle to victory?

Since both strikers and counter strikers were a physical community with FtF contact, the question raised was whether the quality of discourse among them was the same on the ground and in the digital realm. As they admitted, a comment in the Facebook cannot be compared with the conversation you have with another human being. So, while in the factory the conversations were more intense and more analytical, on Facebook it was more relaxed, more summarized. Facebook is up to three lines...

Nevertheless, the counter strikers were interested in what was going on in the Facebook group. We knew that they were reading the group because they mentioned things to us. By the end of the strike, the working force of the factory was divided in two groups with clearly different interests. Their co-existence in the same sphere, may it be a physical or a digital, turned out impossible. On the ground, fierce battles took place almost on a daily basis in front of the plant's gates. In the digital sphere, the counter strikers were excluded from the group once and for all. 
Public spheres, counter public spheres ... and proletarian public spheres: the case of Facebook group of the Hellenic Halyvourgia S.A. strikers in Greece 2011-2012

\section{THE STRIKERS' DISCOURSE}

1078 uploads related to the strike, taken from the photo/video archives of the two Facebook groups, dating from $31^{\text {st }}$ October 2011 to 30 July 2012, were examined and recorded on a monthly basis.

As for the type of the postings, it was subcategorized as follows: videos, photos, uploads from the press, graphic work and announcements on solidarity acts. (table I).

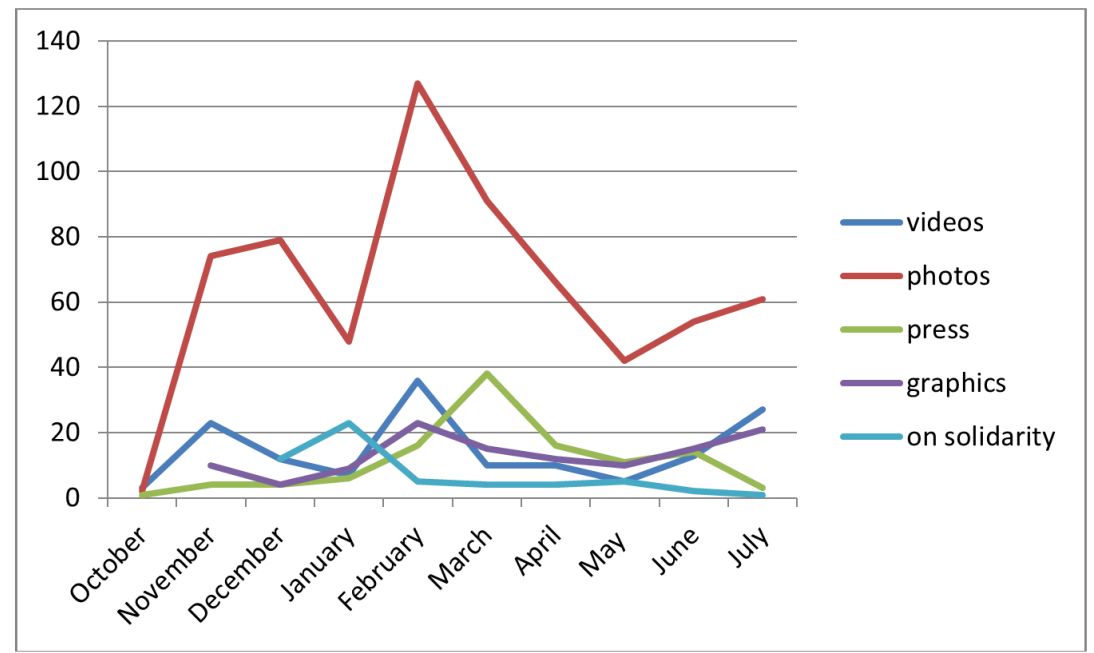

where 'photos and videos' is material recorded mostly by the strikers and their relatives or supporters, under 'press' there is any printed material about the strike, 'graphics' is work done by the strikers through the use of computer graphic tools and, last, 'on solidarity' refers on uploading posters or other printed material produced by the solidarity movement.

The graphic work focused on promoting slogans, or reformatting old labor movement graphics. However, most work has been done in representing in various ways or formats the number of days passed since the beginning of the strike. That became a daily habit which reveals how time counted on the strikers' consciousnesses. Days passing by added up to the magnitude of the struggle - one of the longest in Greece - and the endurance each and everyone showed.

The predominance of photos, seconded by uploaded videos, shows that the strikers engaged in the Facebook groups adopted the role of grassroots reporter. (Gill, 2004). As the display of photos is interwoven with the function of Facebook (Shin, Lee and Park, 2008) uploading photos taken by their mobiles was the first means of communicating both events and feelings unmediated of any verbal burden. The photos multiplied reaching a peak during the months of February, indicating the escalation of both unionist mobility and solidarity movement.

The content of the photos and videos is recorded according to three values: union action, acts of solidarity and the everyday life of the strike (table 2). 


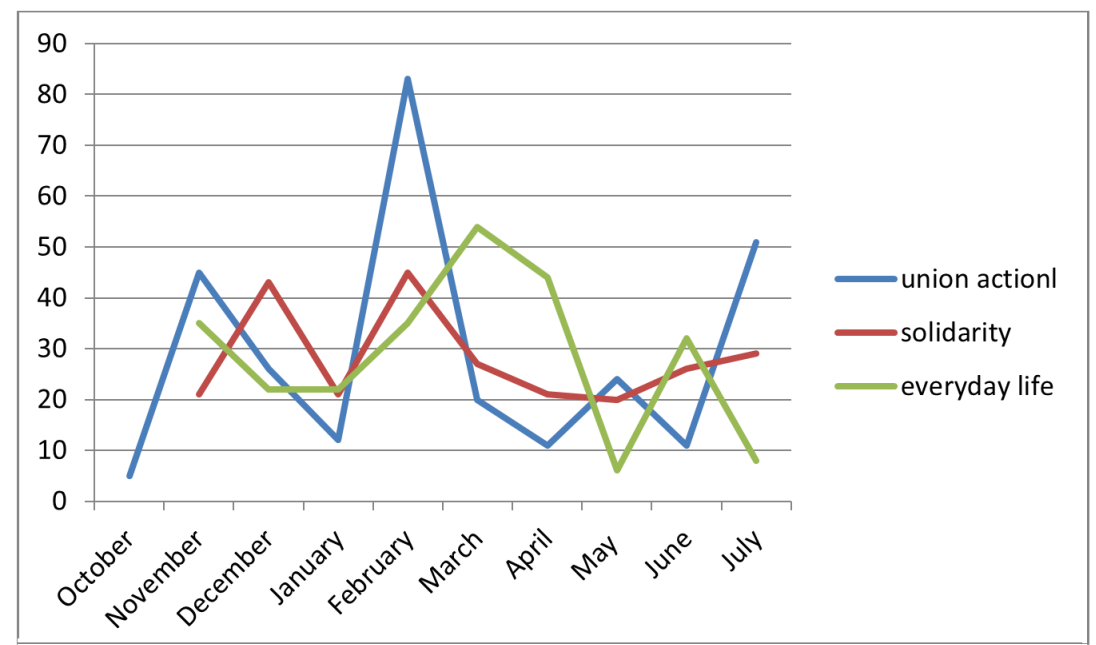

Where union action are general assemblies and mobilizations, the manifestation for the $1^{\text {st }}$ of May in the factory and the clashes that followed the brutal intervention of riot police and as solidarity we consider visits by any kind of institution or collectivity or any other action of solidarity (pictures drawn by children, cultural events organized by supporters, the distribution of solidarity aid, e.t.c.)

Though 'everyday life' may sound strange describing such an event, the strike lasted quite long and acquired features of routine. Photos of the usual Facebook type 'me and my friends' or 'I've been there too' were uploaded next to postings with political content. Photos of the striker's in plant's gate every time of the day, with their wives or their children in the frame, parties and the relaxing scenes of the night shifts with fires set and barbeques allow a different, more intimate look to the worker's universe, it's codes and modes. The peak months for personal uploads were March and April, when the negotiations with the entrepreneur and the Ministry had ceased and the strike had become in a way self-referring.

More than half of the uploads were untitled and uncommented. Reactivity and/or interactivity in the rest is categorized as follows (table 3): 
Public spheres, counter public spheres ... and proletarian public spheres: the case of Facebook group of the Hellenic Halyvourgia S.A. strikers in Greece 2011-2012

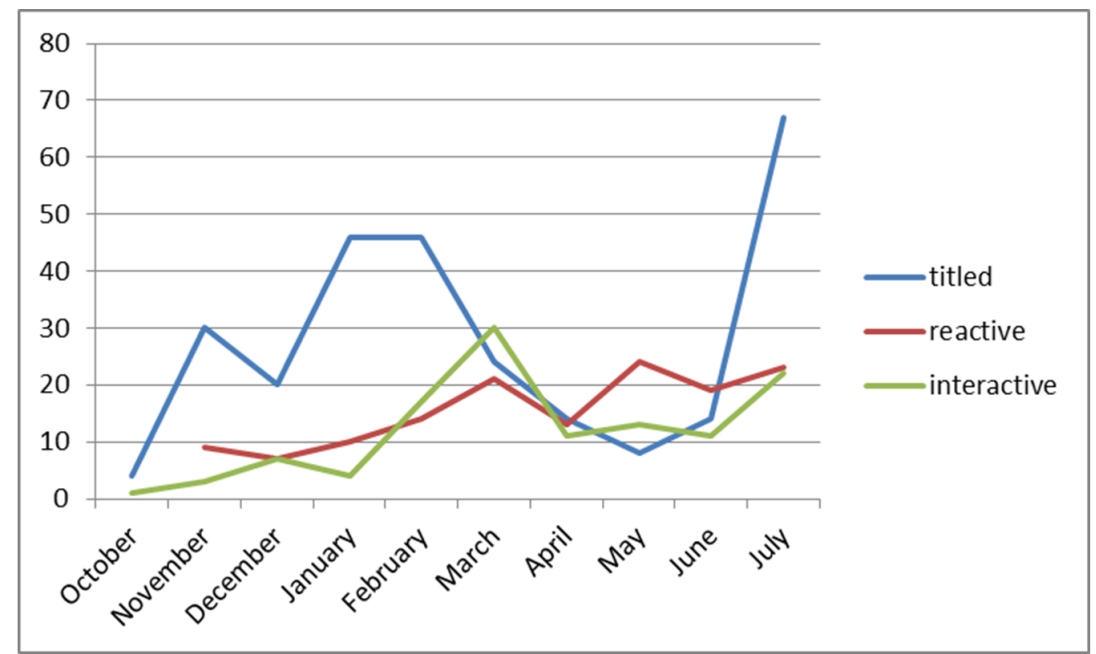

Where 'titled' refers to a short phrase written by the author, 'reactive' refers to up to two comments responding to the preceding message and interactive denotes a long discussion with more than three participants, since interactivity is 'the extent to which messages in a sequence relate to each other, and especially the extent to which later messages recount the relatedness of earlier messages.' (Rafaeli and Sudweeks, 1997)

Most of the uploads are just titled. Nevertheless, the commented and discussed follow an increasing course, which testifies that by the time Facebook became something more than an information source, a reliable forum for both strikers and supporters.

As to the speech uttered by the strikers, there were various stereotyped phrases taken by the assemby's resolutions and repeated by the strikers to describe their right to fight. They attested their will to continue fighting ('Keep strongly and hard' 'Don't wait for us to yield', 'We won't bend our head', 'We keep on', We're still here', 'Until the end), (58 times). Moreover, they propagated their unity (all for one, one for all, we are united as a fist) (31 times) and their conviction that they will win, (18 times) that in fact they were winners since the first day of the strike. The last two graphics, uploaded the day the assembly voted for the suspension of the strike are titled We are winners (in English) and Unity in Suspension. The references on solidarity shown by the rest of the society were very common: The whole Greece is on our side, supporters, financial support, they are with us (51 times). Words common to the Greek social vocabulary that describe society values, as testified by Greek anthropological research, such as pride (Herzfeld, 1990) (2 times) or dignity (5 times) didn't make part of the strikers' vocabulary, neither were incorporated in their everyday speech.

Two people were the most referred to during the strike, even if they didn't participate as members of the group. They were the entrepreneur - owner of the factory and one of the major capitalists in Greece, Nikolaos Manesis, (26 times) and the the factory's union chairman, Giorgos Sifonios, an 'exemplary figure who... won the respect of friends and foes" (Bithymitris 2016:379) 
(27 times). They stood juxtaposed in Facebook as they did in the factory's life, the capital against the working force.

\section{Conclusions}

The nine months strike in $\mathrm{HH}$ was a capital moment of the struggle against austerity in Greece. The neoliberal crisis in Europe, largely known as 'Greek debt crisis', though being a systemic one (Harvey 2014), it was presented by the local elites and their mainstream media as a national and moral problem, caused by both the intervention of the state in entrepreneurship and the moral failures of the people, (Mylonas, 2014), therefore the implementation of cuts in welfare and wages was favored as the only path for the indebted countries to regain their lost competitiveness.

The steelworkers became from the beginning of the strike a 'community of struggle', (Tellez, 2008) that needed a means of self - expression and opted for the use of Facebook. The Facebook group ended in enlarging the community, comprising relatives and supporters of the strike. Its study can lead to conclusions both in the fields of Social Anthropology and CMC studies as for the nature of labor struggles.

On the anthropological aspect, the Facebook group helps define the nature of the enlarged community of struggle and its interaction. The participation of relatives and supporters resulted in a mixed-gendered discourse, from which useful and important conclusions may be extracted. 37 over 106 active members, not 'lurkers', were women, that is a 1/3 of the whole number of the group. The results based on this research show that female discourse was calling for action (even though that in place of 'we' they used plural 'you' referring to the strikers) and was at times equally coarse and abusive. Nevertheless, women could not be faced as whole, as women - relatives and women - supporters belonged to different social groups and had a different cyber behavior and culture. Their social and cultural capital indicated their reactions and their role in the group, asserting that 'in the end the social meanings of the Internet will emerge from particular contexts and practices of usage.' (Van Zoonen 2010).

Furthermore, we could detect an attempt by the side of the strikers to write their own story, that was part of the labor movement's history. They managed to let their own visual version of the struggle the way they experienced it. Together with the stereotyped pictures of well organized demos and workers looking decided and full of class conscience, there comes a digital breach of pictures with smiling colleagues, the head of the union playing guitar, singing under the snow in the night shift, there comes joy, there comes carnivalesque reversal (for the concept of carnival space in the internet see D.K. Herold 2011). What is reversed is the social pretension and political correctness that had enclosed labor struggles in a wrapping paper of assured seriousness, letting playfulness for other forms of social movements deprived, as presumed, of class conflicts. Facebook enabled the people engaged in that nine month struggle to manifest their proper views, even in pictures, on concepts very important for nowadays fights, such as solidarity, willing to fight, awareness of class struggle, in an unconventional way, away from the 'wooden language' of the unionists.

The Facebook group was always in a reciprocating relation to the physical community of struggle. However, what in situ was a closed system that would set its boundaries to distinguish 
itself from other communities, (Cohen, 1989: 12) in cyberspace became a public sphere that would 'enhance dialogue' or even 'defend the working class interests and organize its way to emancipation', as Negt and Kluge stressed back in the turbulent 70's. Passing from community to sphere is indicated by the awareness of the publicity given to the words written on Facebook, exposed to an indefinite audience. The dialogues among strikers and counter strikers were more comprehensive and deprived of emotional outbursts, Facebook dialogue would take place much easier than in a general assembly because space and time was given freely to all members of the group that knew that their words became public, as scripta manet. In this sense, the Facebook public sphere did enhance dialogue.

Was this Facebook group a proletarian - and not just 'counter' - public sphere? Following Negt and Kluge's arguments, the proletarian context of living had managed to turn into a common experience, expressed in order to be shared with others. With the help of the Facebook public sphere, the overall experience of the strike, feelings, aspirations, grief, anger and argumentation, became common good of the community and gained its experiential value. The endless dialogues between strikers and counter strikers prove how painful - and not at all given - the construction of class conscience is, how many obstacles have to be surmounted and how democratic dialogue is not always enough. The factory was no more the 'arcane realm', it became too part of the public sphere. The intimate moments of the struggle were shaped into a common reality that has acquired substance through appearing in the digital public sphere. The everyday discourse gained impetus since it started describing the need for social justice. To conclude, 'massing together serves as a mutual confirmation of their own reality, for who else than the other workers can confirm that their struggle is not a mere illusion'. (Negt and Kluge, 1993:38)

\section{REFERENCES}

Al-Hamalawi H. (2008c). Some notes on the Mahalla uprising, 3arabway, www.arabawy.org/2008 104/27/some-notes-on-the-mahalla-uprising/: Cohen, A.P. (1989). The symbolic construction of community. London. Routledge.

Bithymitris, G. (2016). Union militancy during economic hardship: the strike at the Greek steel company Hellenic Halyvourgia. Employee Relations, 38 (3): 373-389.

Dahlgren, P. (1995). Television and the public sphere: citizenship, democracy and the media. London: Sage Publications.

Dahlgren, P. (2005). The internet, public spheres, and political communication: dispersion and deliberation. Political Communication, 22 (2): 147-162.

Dimitriou, S. (s.d.). 'Solidarity and Dignity' (in Greek), https://antisomata.wordpress.com/2011/1 $0 / 18 /$

Downey J. \& Fenton N. (2003). New media, counter publicity and the public sphere. New Media and Society, 203 (5): 185-202.

Downing, J. D. (2000). Radical media: rebellious communication and social movements: rebellious communication and social movements. London: Sage Publications. 
El Mahdi, R. (2011). Labour protests in Egypt: causes and meanings. Review of African political Economy, 38 (129): 387-402.

Fraser, N. (1990). Rethinking the public sphere: a contribution to the critique actually existing democracy. Social Text, 25/26: 56-80.

Gialis, S. \& Herod, A. (2014). Of steel and strawberries: Greek workers struggle against informal and flexible working arrangements during the crisis. Geoforum, 57: 138-149.

Gill, K. E. (2004, May). How can we measure the influence of the blogosphere. In Www 2004 Workshop on the Weblogging Ecosystem: Aggregation, Analysis and Dynamics. Retrieved from http://s3.amazonaws.com/academia.edu.documents/11024267/10.1.1.124.2509.pdf?A WSAccessKeyId=AKIAJ56TQJRTWSMTNPEA\&Expires $=1473426741 \&$ Signature $=Q E x 4$ z \%2BSGw34ley3IousDwTPk9bY\%3D\&response-content-disposition=inline\%3B\%20filen ame\%3Dhow_can_we_measure_the_influence_of_the.pdf

Habermas, J. (1991). The structural transformation of the public sphere: an inquiry into a category of bourgeois society. (T. Burger \& F. Lawrence Trans.) Cambridge, Massachussets: MIT press. (Original work published 1961).

Habermas, J. (2006). Political communication in media society: does democracy still enjoy an epistemic dimension? the impact of normative theory on empirical research1. Communication theory, 16 (4): 411-426.

Hart, J.; Ridley, C.; Taher, F.; Sas, C. \& Dix, A. (2008, October). Exploring the facebook experience: a new approach to usability. Proceedings of the 5th Nordic conference on Humancomputer interaction: Building bridges (pp. 471-474). ACM.

Harvey, D. (2014). Seventeen contradictions and the end of capitalism. Oxford: University Press.

Helsper, E. J. (2010). Gendered internet use across generations and life stages. Communication Research, doi: 10.1177/0093650209356439

Henley J. (2012, June 14). Greek steelwork strikers still holding out after 228 Days'. The Guardian. www.theguardian.com/world/greek-election-blog-2012/2012/jun/14/greece-steelworks -strike

Herold, D. K. (2011). Introduction: noise, spectacle, politics: carnival in chinese cyberspace. In D. K. Herold \& P. Marolt (eds.), Online society in China: creating, celebrating and instumentalising the online carnival ( $1^{\text {st }}$ ed. pp. 1-20). Abington, Oxon: Routledge

Herring, S. (1994, June). Gender differences in computer-mediated communication: bringing familiar baggage to the new frontier. Keynote talk at American Library Association Annual Convention. Miami , Florida. Retrieved from http://urd.let.rug.nl/welling/cc/Herring-genderdifferences-communication.pdf

Herzfeld, M. (1990). Pride and perjury: time and the oath ih the mountain villages of Crete. MAN New Series, 25 (2): 305-322.

Hofheinz A., (2011). Nextopia? Beyond revolution 2.0. International Journal of Communication, 5: 1417-1434. 
Public spheres, counter public spheres ... and proletarian public spheres: the case of Facebook group of the Hellenic Halyvourgia S.A. strikers in Greece 2011-2012

Jones, S. G. (1997). The internet and its social landscape. In S. G. Jones (ed.), Virtual culture: identity and communication in cybersociety (pp. 7-35). Thousand Oaks, CA: Sage

Kirkpatrick, D. et al. (2011, February, 13). A Tunisian-Egyptian link that shook Arab history. New York Times. pp. 1A.

Knodler-Bunte, E. (1975). The proletarian public sphere and political organization: an analysis of Oscar Negt and Alexander Kluge's the public sphere and experience. (S. Lennox \& F. Lennox Trans.). New German Critique, 4 : 51-75.

McCarthy, J. (2010). Blended learning environments: using social networking sites to enhance the first year experience. Australasian Journal of Educational Technology, 26 (6): 729-740.

Milioni, D. (2009). Probing the online counter public sphere: the case of Indymedia Athens. Media, Culture \& Society, 31 (3): 409-431.

Milioni, D. (2012). Between "identity politics" and "politics of influence": the role of alternative media in the Greek protests in 2008. Estudos em Comunicação, (11): 1-28.

Mottas N. (2012). Greek steel workers strike: 246 days of struggle. Retrieved from www.opednew s.com/articles/Greek-Steel-Workers-Strike-by-Nicolas-Mottas-120719-335.html

Mylonas Y. (2014). Crisis, austerity and opposition in mainstream media discourses in Greece. Critical Discourse Studies, 11 (3): 305-321.

Negt, O. \& Kluge, A. (1993). Public sphere and experience: towards an analysis of the bourgeois and proletarian public sphere. (P. Labanyi, J. O. Daniel \& A. Oksiloff Trans.). Minneapolis and London: University of Minnesota Press.

Papacharissi, Z. (2002). The virtual sphere - the internet as a public sphere. New Media and Society, 4 (1): 9-27.

Pickerill, J. (2007). 'Autonomy online': indymedia and practices of alter-globalisation. Environment and Planning A, 39 (11): 2668-2684.

Platon, S. \& Deuze, M. (2003). Indymedia journalism a radical way of making, selecting and sharing news?. Journalism, 4 (3): 336-355.

Rafaeli, S. \& Sudweeks, F. (1997). Networked interactivity. Journal of Computer Mediated Communcation, 2: 0. doi: 10.1111/j.1083-6101.1997.tb00201.x

Royal, C. (2008). Framing the internet: a comparison of gendered studies. Social Science Computer Review, 26: 152-169.

Sallam, H. (2011). Striking back in egyptian workers. Middle East Research and Information Project, 41: 20-25.

Savicki, V.; Lingenfelter, D. \& Kelley, M. (1996). Gender language style and group composition in internet discussion groups. Journal of Computer-Mediated Communication, 2 (3), vol. 2, iss. 3. DOI: 10.1111/j.1083-6101.1996.tb00191.x

Shim, M.; Lee, M. J. \& Park, S. H. (2008, August). Photograph use on social network sites among south korean college students: the role of public and private self-consciousness. CyberPsychology \& Behavior, 11 (4): 489-493. 
Smith, J. (2001). Cyber subversion in the information economy. Dissent, 48 (2): 48-52.

Spot On (2010). Egypt Facebook demographics. [Data file] retrieved from www.spotonpr.com/egy pt-Facebook-demographics/

Tellez, M. (2008). Community of struggle - gender, violence and resistance on the U.S - Mexican border. Gender and Society, 22 (5): 545-567.

Van Zoonen, L. (2002). Gendering the internet. Claims, controversies and cultures. European Journal of Communication, 17 (1): 5-23.

Warner, M. (2002). Publics and counterpublics. Public Culture, 14 (1): 49-90.

Waterman, P. (1992). International labour communication by computer: the fifth international?. $\left(\mathrm{n}^{\mathrm{o}}\right.$ 18873). International Institute of Social Studies of Erasmus University Rotterdam (ISS), The Hague.

Zhao, S. (2006, February). Cyber-gathering places and online-embedded relationships. Annual meetings of the eastern sociological society in Boston.

Zhao S.; Grasmuck S. \& Martin, J. (2008). Identity construction on Facebook: digital empowerment in anchored relationships. Computers in Human Behavior, 24: 1816-1836. 